http://ejournal.uhn.ac.id/index.php/opinion

\title{
PERLINDUNGAN HUKUM BAGI KONSUMEN YANG DATA PRIBADINYA DIPERJUAL BELIKAN DI APLIKASI FINTECH PEER-TO- PEER LENDING
}

\author{
Roida Nababan ${ }^{1}$, Nelson Persada Sinaga ${ }^{2}$ \\ ${ }^{1,2}$ Program Studi Ilmu Hukum \\ Universitas HKBP Nommensen, Medan-Sumatera Utara-Indonesia \\ e-mail: roidanababan@uhn.ac.id
}

\begin{abstract}
The influence of globalization brings many influences in the progress of life. The rapid development that can be seen from the era of globalization is the development in the field of information technology, especially financial applications. Applications that are developing in the financial services sector are fintech applications. The increase in the use of fintech applications leads to abuse of the fintech application itself. Misuse of personal data of fintech consumers is by buying and selling personal data of fintech consumers. Facts related to the misuse of consumer personal data in fintech applications for sale are circulating on social media. The sale and purchase of consumer personal data using this fintech application was confirmed by a cybersecurity observer from Vaccines.com, Alfons Tanujaya, to CNN Indonesia. The sale and purchase of consumer personal data has violated Article 4 letter a of Law Number 8 of 1999 concerning Consumer Protection, hereinafter referred to as UUPK which states: "Consumers' rights are rights to comfort, security, and safety in consuming goods and/or services." Buying and selling of consumer personal data on fintech applications violates consumers' rights to obtain safety, convenience, and security when using fintech applications.
\end{abstract}

Keywords: Legal Protection, Misuse of Personal Data, Consumers, Fintech

\begin{abstract}
Abstrak
Pengaruh globalisasi membawa banyak pengaruh dalam kemajuan kehidupan. Perkembangan pesat yang dapat dilihat dari adanya era globalisasi adalah perkembangan di bidang teknologi informasi khususnya aplikasi keuangan. Aplikasi yang berkembang dalam bidang sektor jasa keuangan adalah aplikasi fintech. Peningkatan penggunaan aplikasi fintech berujung pada penyalahgunaan aplikasi fintech itu sendiri. Penyalahgunaan data pribadi konsumen fintech yaitu dengan melakukan jual beli data pribadi konsumen fintech. Fakta terkait penyalahgunaan data pribadi konsumen pada aplikasi fintech untuk diperjualbelikan marak beredar di media sosial. Jual beli data pribadi konsumen pengguna aplikasi fintech ini dibenarkan oleh pengamat keamanan siber dari Vaksin.com yaitu Alfons Tanujaya kepada CNN Indonesia. Jual beli data pribadi konsumen telah melanggar Pasal 4 huruf a UndangUndang Nomor 8 Tahun 1999 Tentang Perlindungan Konsumen untuk selanjutnya disebut dengan UUPK yang menyatakan: "Hak konsumen adalah hak atas kenyamanan, keamanan, dan keselamatan dalam mengkonsumsi barang dan/atau jasa." Jual beli data pribadi konsumen pada aplikasi fintech melanggar hak konsumen untuk mendapatkan keselamatan, kenyamanan, dan keamanan pada saat menggunakan aplikasi fintech.

Kata kunci: Perlindungan Hukum, Penyalahgunaan Data Pribadi, Konsumen, Fintech
\end{abstract}




\section{A. Pendahuluan}

Pengaruh globalisasi membawa banyak pengaruh dalam kemajuan kehidupan. Perkembangan pesat yang dapat dilihat dari adanya era globalisasi adalah perkembangan di bidang teknologi informasi. Perkembangan teknologi informasi yang dapat dilihat secara langsung adalah penggunaan internet.Kegiatan perekonomian dengan menggunakan internet berkembang secara pesat sehingga mendorong perkembangan dalam bidang perekonomian salah satu perkembangannya yaitu terdapatnya aplikasi perekonomian khusunya aplikasi keuangan. Aplikasi yang berkembang dalam bidang sektor jasa keuangan adalah aplikasi fintech. Aplikasi Fintech muncul sebagai bentuk perkembangan dalam dunia perekonomian khususnya dalam bidang keuangan. Aplikasi fintech adalah aplikasi perpaduan dari kemajuan teknologi informasi dengan sektor jasa keuangan. Aplikasi fintech menghasilkan aplikasi yang mempermudah konsumen di bidang jasa keuangan. Menurut Departemen Perlindungan Konsumen, Financial Technology atau disingkat fintech adalah pemanfaatan perkembangan teknologi informasi dengan sektor jasa keuangan untuk meningkatkan layanan di industri keuangan. ${ }^{1}$ Aplikasi fintech bertujuan untuk meningkatkan pelayanan pada sektor jasa keuangan.

Jual beli data pribadi konsumen fintech dilakukan dengan menawarkan data pribadi konsumen pada situs-situs yang telah dibuat untuk jual beli data pribadi.Jual beli data pribadi konsumen telah melanggar Pasal 4 huruf a Undang-Undang Nomor 8 Tahun 1999 Tentang Perlindungan Konsumen untuk selanjutnya disebut dengan UUPK yang menyatakan: "Hak konsumen adalah hak atas kenyamanan, keamanan, dan keselamatan dalam mengkonsumsi barang dan/atau jasa.” Jual beli data pribadi konsumen pada aplikasi fintech melanggar hak konsumen untuk mendapatkan keselamatan.

Jual beli data pribadi konsumen fintech juga telah melanggar Pasal 26 huruf a Peraturan Otoritas Jasa Keuangan Nomor 77/POJK.o1/2016 Tentang Layanan Pinjam Meminjam Uang Berbasis Teknologi Informasi yang menyatakan: "Penyelenggara wajib: Menjaga kerahasiaan, keutuhan, ketersediaan data pribadi, data transaksi, dan data keuangan yang dikelolanya sejak data diperoleh hingga data tersebut dimusnahkan".

\section{B. Metode Penelitian}

Sehubungan dengan tipe penelitian yang digunakan yakni Yuridis normatif, maka karya ilmiah ini menggunakan pendekatan konseptual dan pendekatan undangundang (statute approach). Pendekatan perundang-undangan (statute approach) dilakukan dengan menelaah pada undang-undang dan peraturan terkait dengan isu hukum yang diteliti. Hasil atas pendekatan undang-undang tersebut yaitu berbentuk

\footnotetext{
${ }^{1}$ Sarwin Kiko Napitupulu dkk, 2017 Kajian Perlindungan Konsumen Sektor Jasa Keunagan:Perlindungan Konsumen Pada Fintech. (Jakarta: Otoritas Jasa Keungan), hal.8
} 
http://ejournal.uhn.ac.id/index.php/opinion

argumen yang digunakan dalam memecahkan isu yang diteliti. ${ }^{2}$ Pendekatan konseptual (conceptual approach) merupakan pendekatan yang telah berpindah atas pandangan dan doktrin yang terdapat dalam hukum sehingga memudahkan ditemukan ide-ide sehingga dapat memunculkan pengertian- pengertian hukum, konsep-konsep hukum, dan asas-asas hukum yang relevan dengan isu yang diteliti. ${ }^{3}$

\section{Pembahasan}

\section{Pengaturan Hukum Positif Terhadap Jual Beli Data Pribadi Konsumen Di Aplikasi Fintech}

Model bisnis $\mathrm{P}_{2} \mathrm{P}$ Lending yaitu calon Penerima Pinjaman melakukan registrasi di platform, kemudian mengajukan pinjaman melalui platform. Penyelenggara kemudian melakukan verifikasi data calon Penerima Pinjaman, kemudian menampilkan pengajuan pinjaman di platform marketplace. Pemberi Pinjaman melakukan registrasi di platform, kemudian dapat memilih pinjaman mana yang akan didanai di platform marketplace dan melakukan pendanaan. ${ }^{4}$

Biasanya layanan pinjaman online akan meminta konsumennya untuk mengunggah data dan dokumen seperti KTP, NPWP, slip gaji dan lain sebagainya. Jika kamu memberikan data dan dokumen palsu dan tidak lengkap otomatis pengajuan pinjaman kamu akan gagal. ${ }^{5}$

Aturan yang berlaku saat ini mengenai data pribadi masih termuat terpisah dan tersebar di beberapa undang-undang dan hanya mencerminkan aspek perlindungan data pribadi secara umum. Meski demikian, setidaknya dalam peraturan tingkat menteri, Menteri Komunikasi dan Informatika telah mengeluarkan Peraturan Menteri Komunikasi dan Informatika Nomor 20 Tahun 2016 Perlindungan Data Pribadi Dalam Sistem Elektronik. Adapun peraturan yang mengatur mengenai keamanan data pribadi yang peneliti ambil dalam penelitian ini adalah sebagai berikut:

\section{a. Peraturan Menkominfo No. 20 Tahun 2016 tentang Perlindungan Data Pribadi Dalam Sistem Elektronik.}

Pasal Pasal 1 angka 1 Perkominfo No. 20 Tahun 2016 mengatakan Data pribadi adalah data perseorangan tertentu yang disimpan, dirawat dan dijaga kebenaran serta dilindungi kerahasiaannya. Perlindungan data pribadi dalam sistem elektronik mencakup perlindungan terhadap perolehan, pengumpulan, pengolahan, penganalisisan, penyimpanan, penampilan, pengumuman, pengiriman, penyebarluasan dan pemusnahan data pribadi (Pasal 3 Perkominfo No. 20 Tahun 2016).Pelaksanaan perlindungan data pribadi dalam sistem elektronik harus berdasarkan pada asas penghormatan terhadap data pribadi sebagai privasi.

\footnotetext{
${ }^{2}$ Peter Mahmud Marzuki, Penelitian Hukum, cetakan keduabelas, (Jakarta: Prenada Media Group, 2016), hal.133 ${ }^{3}$ Ibid, hal. 137

${ }^{4}$ Moch. Najib Imanullah, 2020, Aspek Hukum Peer To Peer Lending (Identifikasi Permasalahan Hukum dan Mekanisme Penyelesaian), Jurnal Privat Law Volume 8 Nomor 1, hal. 152

${ }^{5}$ https://maucash.id/pinjaman-online-langsung-cair-tanpa-ribet diakses pada tanggal, 17 Juni 2021, pukul 16:46 WIB 
Menampilkan, mengumumkan, mengirimkan, menyebarluaskan, dan/atau membuka akses Data Pribadi dalam Sistem Elektronik hanya dapat dilakukan: atas Persetujuan kecuali ditentukan lain oleh ketentuan peraturan perundang-undangan; dan setelah diverifikasi keakuratan dan kesesuaian dengan tujuan perolehan dan pengumpulan Data Pribadi tersebut (Pasal 21 No. 20 Tahun 2016).

Setiap pemilik data pribadi memiliki hak atas datanya dalam sistem elektronik. Hakhak tersebut diatur dalam Pasal 26, yaitu: berhak atas kerahasiaan data pribadinya; mengajukan pengaduan dalam rangka penyelesaian sengketa data pribadi atas kegagalan perlindungan kerahasiaan data pribadinya oleh penyelenggara sistem elektronik kepada menteri; mendapatkan akses atau kesempatan untuk mengubah atau memperbarui data pribadinya tanpa mengganggu sistem pengelolaan data pribadi, kecuali ditentukan lain oleh ketentuan peraturan perundang-undangan; mendapatkan akses atau kesempatan untuk memperoleh historis data pribadinya yang pernah diserahkan kepada penyelenggara sistem elektronik sepanjang masih sesuai dengan ketentuan peraturan perundang-undangan; dan meminta pemusnahan data perseorangan tertentu miliknya dalam sistem elektronik yang dikelola oleh penyelenggara sistem elektronik, kecuali ditentukan lain oleh ketentuan peraturan perundang-undangan.

Dalam Pasal 27 Perkominfo No. 20 Tahun 2016 mengatakan, Pengguna sistem elektronik memiliki kewajiban untuk menjaga kerahasiaan data pribadi yang diperoleh, dikumpulkan, diolah, dan dianalisisnya; menggunakan data pribadi sesuai dengan kebutuhan pengguna saja; melindungi data pribadi beserta dokumen yang memuat data pribadi tersebut dari tindakan penyalahgunaan; dan berta-nggung jawab atas data pribadi yang terdapat dalam penguasaannya, baik penguasaan secara organisasi yang menjadi kewenangannya maupun perorangan, jika terjadi tindakan penyalahgunaan.

Pasal 28 Perkeminfo No. 20 Tahun 2016 : Penyelenggara sistem elektronik memiliki kewajiban untuk melakukan sertifikasi sistem elektronik yang dikelolanya sesuai dengan ketentuan peraturan perundang-undangan; menjaga kebenaran, keabsahan, kerahasiaan, keakuratan dan relevansi serta kesesuaian dengan tujuan perolehan, pengumpulan, pengolah-an, penganalisisan, penyimpanan, penampilan, pengumuman, pengiriman, penyebarluasan dan pemusnahan data pribadi; memberitahukan secara tertulis kepada pemilik data pribadi jika terjadi kegagalan perlindungan rahasia data pribadi dalam sistem elektronik yang dikelolanya; memiliki aturan internal terkait perlindungan data pribadi yang sesuai dengan ketentuan peraturan perundang-undangan; menyediakan rekam jejak audit terhadap seluruh kegiatan penyelenggaraan sistem elektronik yang dikelolanya; memberikan opsi kepada pemilik data pribadi mengenai data pribadi yang dikelolanya dapat/atau tidak dapat digunakan dan/atau ditampilkan oleh/pada pihak ketiga atas persetujuan sepanjang masih terkait dengan tujuan perolehan dan pengumpulan data pribadi; memberi-kan akses atau kesempatan kepada pemilik data pribadi untuk mengubah atau memperbarui data pribadinya tanpa menganggu sistem pengelolaan data pribadi, kecuali ditentukan lain oleh ketentuan peraturan perundang-undangan; memusnahkan data pribadi sesuai dengan ketentuan dalam Peraturan Menteri ini atau ketentuan peraturan perundang-undangan lainnya yang secara khusus mengatur 
di masing-masing instansi pengawas dan pengatur sektor untuk itu; dan menyediakan narahubung (contact person) yang mudah dihubungi oleh pemilik data pribadi terkait pengelolaan data pribadinya.

Mengenai sanksi diatur dalam Pasal 36 Perkominfo No. 20 Tahun 2016 yang berbunyi: Setiap pihak yang memperoleh, mengumpulkan, mengolah, menganalisis, menyimpan, menampilkan, mengumumkan, mengirimkan dan/atau menyebarluaskan data pribadi tanpa hak atau bertentangan dengan peraturan ini serta peraturan perundang-undangan yang lain akan dikenakan sanksi administratif berupa peringatan lisan, peringatan tertulis, penghentian sementara kegiatan dan/atau pengumuman di situs dalam jaringan (website online).

\section{b. POJK No.13/POJK.o2/2018 tentang Inovasi Keuangan Digital di Sektor} Jasa Keuangan.

Menurut POJK ini, penyelenggara bisnis Fintech wajib menjaga kerahasiaan, keutuhan, dan ketersediaan data pribadi, data transaksi dan data keuangan yang dikelolanya sejak data diperoleh hingga data tersebut dimusnahkan. ${ }^{6}$ Pasal 30 ayat (2) POJK No.13/POJK.02/2018 mengatakan Syarat pemanfaatan data dan informasi pengguna antara lain:

a. memperoleh persetujuan dari pengguna;

b. menyampaikan batasan pemanfaatan data dan informasi kepada pengguna;

c. menyampaikan setiap perubahan tujuan pemanfaatan data dan informasi kepada pengguna dalam hal terdapat perubahan tujuan pemanfaatan data dan informasi; dan

d. media dan metode yang digunakan dalam memperoleh data dan informasi terjamin kerahasiaan, keamanan serta keutuhannya.

Dalam Pasal 31, penyelenggara diwajibkan untuk menerapkan prinsip dasar perlindungan konsumen yaitu: transparansi, perlakuan yang adil, keandalan, kerahasiaan dan keamanan data/informasi konsumen, penanganan pengaduan serta penyelesaian sengketa konsumen secara sederhana, cepat dan biaya terjangkau. Selain itu, penyelenggara juga wajib menyediakan pusat pelayanan konsumen berbasis teknologi yang paling sedikit terdiri atas penyediaan pusat layanan konsumen yang dapat dilaksanakan sendiri atau melalui pihak lain.

Pasal 39 mengatur bahwa setiap pihak yang melanggar atau menyebabkan pelanggaran terhadap POJK ini akan dikenakan sanksi administratif berupa peringatan tertulis, kewajiban membayar denda dalam bentuk uang, pembatalan persetujuan dan/atau, pembatalan pendaftaran. Sanksi yang

\footnotetext{
${ }^{6}$ Kornelius Benuf, Siti Mahmudah, Ery Agus Priyono, 2019, Perlindungan Hukum Terhadap Keamanan Data Konsumen Financial Technology Di Indonesia, Jurnal Ilmu Hukum Universitas Kristen Satya Wacana, Volume 3 No 2, hal.151
} 
dikenakan OJK ini tidak mengurangi ketentuan pidana di sektor jasa keuangan.

\section{c. POJK No.77 /POJK.o1/2016 tentang Layanan Pinjam Meminjam Uang Berbasis Teknologi Informasi.}

Perlindungan data konsumen yang berkaitan dengan data pribadi di atur dalam Pasal 26. Pasal tersebut mewajibkan penyelenggara untuk menjaga kerahasiaan data pribadi pengguna jasa. Kemudian Pasal 29 mengatur bahwa penyelenggara wajib menerapkan prinsip dasar perlindungan pengguna yaitu transparansi, perlakuan yang adil, keandalan, kerahasiaan dan keamanan data serta penyelesaian sengketa pengguna secara sederhana, cepat dan biaya terjangkau.

Selain kewajiban, di pasal 39 penyelenggara juga dilarang untuk memberikan data dan/atau informasi mengenai pengguna kepada pihak ketiga dengan cara apapun kecuali pengguna memberikan persetujuan secara elektronik dan/atau karena diwajibkan oleh ketentuan peraturan perundang-undangan. Apabila penyelenggara melanggar kewajiban dan larangan dalam POJK ini, maka akan dikenakan sanksi administratif. Sanksi tersebut berupa peringatan tertulis, kewajiban membayar denda dalam bentuk uang, pembatasan kegiatan usaha dan pencabutan izin.

\section{d. POJK No.1/POJK.o7/2o13 tentang Perlindungan Konsumen Sektor Jasa}

\section{Keuangan.}

Pasal 2 mengatur mengenai prinsip dari perlindungan konsumen yang harus disediakan bagi konsumen, termasuk didalamnya konsumen Fintech sebagai pengguna jasa keuangan. Prinsip tersebut adalah transparansi, perlakuan yang adil, keandalan, kerahasiaan dan keamanan data/informasi konsumen, penanganan pengaduan serta penyelesaian sengketa konsumen secara sederhana, cepat dan biaya terjangkau. Selanjutnya Pasal 31 mengatur mengenai larangan yang berkaitan dengan data konsumen bagi Pelaku Usaha Jasa Keuangan (selanjutnya disebut PUJK). Larangan tersebut adalah tidak memberikan data dan/atau informasi mengenai konsumennya kepada pihak ketiga dengan cara apapun kecuali dengan ijin tertulis dari konsumen dan atau karena diwajibkan oleh peraturan perundang-undangan. Selain larangan, Pasal 49 juga mewajibkan PUJK memiliki dan menerapkan kebijakan dan prosedur tertulis perlindungan konsumen. Kebijakan tersebut wajib dituangkan dalam standar prosedur operasional yang kemudian dijadikan panduan dalam seluruh kegiatan operasional PUJK.

Pelanggaran terhadap POJK ini akan dikenakan sanksi administratif sebagaimana yang dimaksud dalam Pasal 53. Sanksi administratif tersebut berupa: peringatan tertulis, denda untuk membayar sejumlah uang tertentu, pembatasan kegiatan usaha, pembekuan kegiatan usaha dan pencabutan izin 
kegiatan usaha. Pengaturan secara khusus mengenai Fintech oleh OJK bisa ditemukan dalam Surat Edaran Otoritas Jasa Keuangan No. 14/ SEOJK.o7/2014 tentang Kerahasiaan dan Keamanan Data dan/atau Informasi Pribadi Konsumen dan Surat Edaran Otoritas Jasa Keuangan Nomor 18 /SEOJK. 02/2017 tentang Tata Kelola dan Manajemen Risiko Teknologi Informasi Pada Layanan Pinjam Meminjam Uang Berbasis Teknologi Informasi.

Berdasarkan peraturan perundang-undangan diatas tentang kerahasiaan data pribadi seseorang maka dapat disimpulkan bahwa jual beli data pribadi pada aplikasi fintech jelas melanggar pengaturan hukum positif data pribadi di Indonesia karena melanggar dari kerahasiaan data pribadi seseorang tersebut, kecuali hal tersebut telah di setujui oleh yang bersangkutan sesuai ketentuan Undang-Undang Nomor 19 Tahun 2016 tentang Perubahan Atas UndangUndang Nomor 11 Tahun 2008 tentang Informasi dan Transaksi Elektronik Pasal 26 ayat (1) mengatakan "Kecuali ditentukan lain oleh peraturan perundang-undangan, penggunaan setiap informasi melalui media elektronik yang menyangkut data pribadi seseorang harus dilakukan atas persetujuan Orang yang bersangkutan".

\section{Upaya penyelesaian yang dapat dilakukan konsumen yang mengalami kerugian} akibat data pribadinya yang diperjualbelikan di aplikasi fintech.

Seperti kasus yang dialami oleh pengguna Twitter bernama Robby Rachman pada 2 April 2021 lalu mencuitkan dirinya menerima dua kali transfer dana masing-masing sebesar Rp 804 ribu dari nomor rekening tak dikenal. Kemudian pada 5 April 2021, tiba-tiba dia menerima pesan WhatsApp berupa tagihan utang dari pinjaman online disertai ancaman. Padahal dia tak pernah meminjam uang dari platform manapun. Dia diminta untuk membayar dana dua kali pinjaman masing-masing sebesar Rp 1,2 juta. Menurut Robby, penagih pinjaman itu mengatasnamakan KSP Hidup Hijau. Perusahaan tersebut diketahui merupakan salah satu dari 86 fintech ilegal yang telah diblokir Otoritas Jasa Keuangan (OJK) pada April lalu. Ada pula pengguna Twitter bernama Zomet, yang mencuitkah kisah ketika dirinya yang tiba-tiba didatangi lima orang debt collector ke rumahnya. Mereka menagih utang sembari merusak pot bunga. Padahal dia mengaku tak pernah meminjam uang. Diketahui bahwa seseorang bernama Yendra meminjam uang dengan menggunakan alamat rumahnya. ${ }^{7}$

Pasal 2Undang-undang No.8 Tahun 1999 Tentang Perlindungan Konsumen mengamanatkan salah satu hak konsumen adalah hak atas keamanan. Keamanan dalam hal ini juga dapat berupa keamanan atas informasi pribadi konsumen ketika sedang menggunakan produk pelaku usaha. Produk yang dimaksud dalam hal ini yaitu aplikasi pinjaman online yang memerlukan registrasi awal dengan mengisi informasi data pribadi pengguna seperti data diri, NIK dan nomor KK. Selain hak atas keamanan,

\footnotetext{
7 https://katadata.co.id/ariayudhistira/analisisdata/6o9a43a46aa5e/pencurian-data-pribadi-dalam-pusaran-bisnisfintech-ilegal. Diakses pada tanggal 23 juli 2021, Pukul 15:32 WIB
} 
hak atas kenyamanan juga diakomodir oleh UUPK sebagai salah satu hak konsumen. Jual beli data pribadi tentu membuat merasa terganggunya kenyamanan konsumen dengan aktivitas pelaku usaha yang diluar kesepakatan dengan konsumen.

Upaya yang dapat dilakukan oleh Sdr. Robby dan Zomet akibat data pribadinya yang bocor diatas sesuai pasal 26 Huruf b Perkominfo No.20 Tahun 2016 yang berbunyi: Setiap pemilik data pribadi berhak mengajukan pengaduan dalam rangka penyelesaian sengketa Data Pribadi atas kegagalan perlindungan kerahasiaan Data Pribadinya oleh Penyelenggara Sistem Elektronik kepada Menteri. Mengenai pengaduan ini juga di sebutkan di pasal 29 ayat (1) yang berbunyi: Setiap Pemilik Data Pribadi dan Penyelenggara Sistem Elektronik dapat mengajukan pengaduan kepada Menteri atas kegagalan perlindungan kerahasiaan Data Pribadi. Adapun penyelesaian sengketa yang dilakukan adalah non litigasi yaitu secara musyawarah atau alternatif lainnya (pasal 29 ayat (2) Perkominfo No. 20 Tahun 2016).

Jika Dalam upaya penyelesaian sengketa secara musyawarah atau melalui upaya penyelesaian alternatif lainnya belum mampu menyelesaikan sengketa atas kegagalan perlindungan kerahasiaan Data Pribadi, maka pihak yang dirugikan dapat melakukan upaya litigasi yaitu mengajukan gugatan atas terjadinya kegagalan perlindungan rahasia Data Pribadi, Gugatan sebagaimana dimaksud hanya berupa gugatan perdata dan diajukan sesuai dengan ketentuan peraturan perundangundangan (Pasal 32 Perkominfo No. 20 Tahun 2016). Sanksi atas pelanggaran yang di atur dalam Perkominfo dalam pasal 36 berupa sanksi administratif yaituperingatan lisan, peringatan tertulis, penghentian sementara kegiatan, dan/atau pengumuman di situs dalam jaringan (website online).

Jalur penyelesaian sengketa terdapat dua jenis yaitu jalur litigasi dan non litigasi. ${ }^{8}$ Menurut Suyud Margono berpendapat bahwa litigasi adalah gugatan atas suatu konflik yang diritualisasikan untuk menggantikan konflik sesungguhnya, dimana para pihak memberikan kepada seorang pengambilan keputusan dua pilihan yang bertentangan. ${ }^{9}$ Litigasi merupakan proses penyelesaian sengketa di pengadilan, di mana semua pihak yang bersengketa saling berhadapan satu sama lain untuk mempertahankan hak-haknya di muka pengadilan. Hasil akhir dari suatu penyelesaian sengketa melalui litigasi adalah putusan yang menyatakan win-lose solution. ${ }^{10}$ Prosedur dalam jalur litigasi ini sifatnya lebih formal (very formalistic) dan sangat teknis (very technical). Seperti yang dikatakan J. David Reitzel "there is a long wait for litigants to

\footnotetext{
${ }^{8}$ Nasrudin, 2020, Upaya Penyelesaian Sengketa Pada Bisnis Pariwisata Di Tengah Pandemi Covid 19, Fakultas Syari'ah dan Hukum UIN Sunan Gunung Djati Bandung, vol 14, hal.84

${ }^{9}$ Suyud Margono, Penyelesaian Sengketa Bisnis: Alternative Dispute Resolution (ADR) : Teknik E Strategi Dalam Negosiasi, Mediasi E Arbitrase, (Bandung: Pustaka Reka Cipta, 2015), hal. 34

${ }^{10}$ Nurnaningsih Amriani, Mediasi Alternatif Penyelesaian Sengketa di Pengadilan, (Jakarta: Grafindo Persada, 2012), hal.16
} 
get trial", jangankan untuk mendapat putusan yang berkekuatan hukum tetap, untuk menyelesaikan pada satu instansi peradilan saja, harus antri menunggu. ${ }^{11}$

Sedangkan Penyelesaian sengketa melalui non litigasi jauh lebih efektif dan efisien sebabnya pada masa belakangan ini, berkembangnya berbagai cara penyelesaian sengketa (settlement method) di luar pengadilan, yang dikenal dengan Alternative Dispute Resolution (ADR) Atau Alternatif Penyelesaian Sengketa (APS) dalam berbagai bentuk, yaitu: Arbitrase, Negosiasi, Mediasi, Konsiliasi, dan Penilaian Ahli. ${ }^{12}$

Adapun skema upaya penyelesaian sengketa yang dapat dilakukan adalah sebagai berikut:

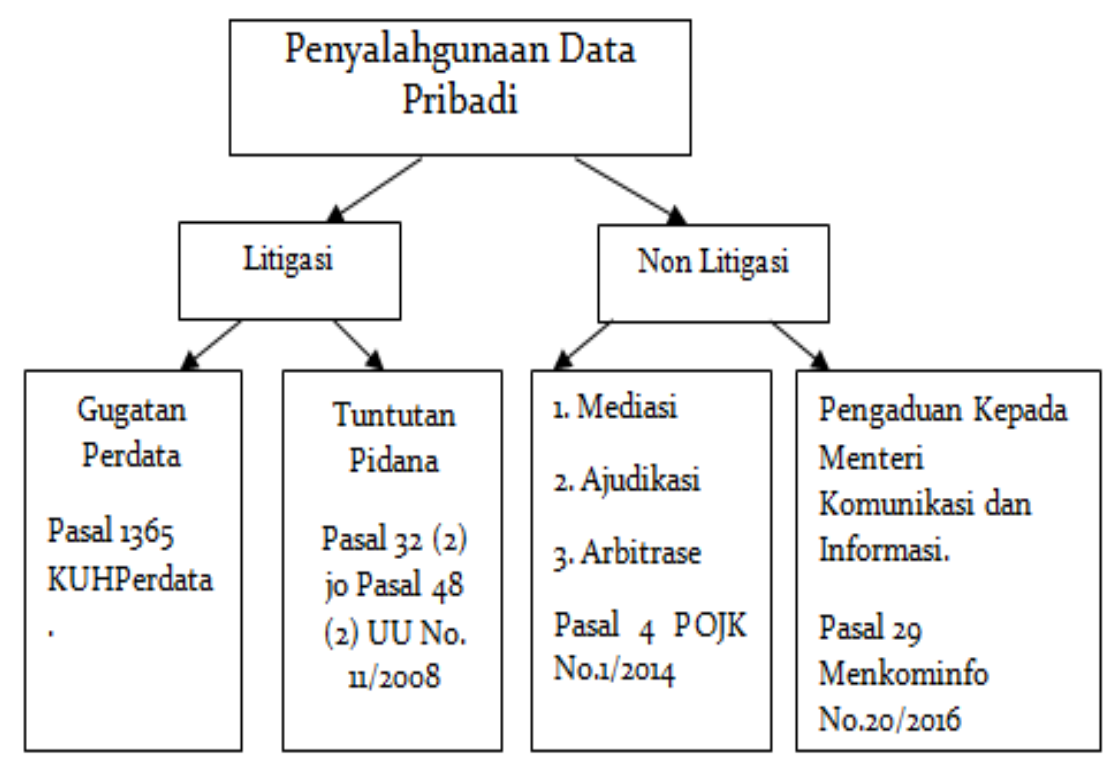

\section{Litigasi}

Upaya jalur litigasi yang dapat dilakukan konsumen yang dirugikan akibat penyalahgunaan data pribadi ini adalah Mengajukan Gugatan PMH Ke Pengadilan. Disebutkan dalam Pasal 26 ayat 1 dan 2 Undang-Undang Nomor 19 Tahun 2016 tentang Perubahan Undang-Undang Nomor 11 Tahun 2008 tentang Informasi Dan Transaksi Elektronik (UU 19/2016): Kecuali ditentukan lain oleh peraturan perundang-undangan, penggunaan setiap informasi melalui media elektronik yang menyangkut data pribadi seseorang harus dilakukan atas persetujuan Orang yang bersangkutan. Setiap Orang yang dilanggar haknya dapat mengajukan gugatan atas kerugian yang ditimbulkan berdasarkan Undang-Undang ini.

Jika seseorang merasa dirugikan karena identitasnya digunakan dalam penyalahgunaan data pribadi, maka ia dapat mengajukan gugatan atas kerugian yang diperoleh, gugatan yang dimaksud adalah gugatan Perbuatan Melawan Hukum

\footnotetext{
${ }^{11}$ Yahya Harahap, Hukum Acara Perdata Tentang Gugatan, Persidangan, Penyitaan, Pembuktian, dan Putusan Pengadilan, (Jakarta: Sinar Grafika, 2009), hal.233

${ }^{12}$ Ibid, hal.236
} 
(PMH). PMH diatur dalam Pasal 1365 Kitab Undang-Undang Hukum Perdata (KUHPerdata) yang berbunyi: Tiap perbuatan melanggar hukum, yang membawa kerugian kepada orang lain, mewajibkan orang yang karena salahnya menerbitkan kerugian itu, mengganti kerugian tersebut".

Jalur litigasi merupakan upaya terakhir dimana para pihak yang bersengketa tidak menemukan titik temu pada saat dilakukan mediasi atau diselesaikan secara kekeluargaan. Pengadilan sebagai lembaga litigasi yang menangani penyelesaian sengketa di antara kedua belah pihak. Dalam prosesnya, pengadilan mengadili sengketa dengan aturan hukum yang berlaku.

\section{Non Litigasi}

Adapun upaya jalur non litigasi yang dapat dilakukan konsumen yang dirugikan akibat penyalahgunaan data pribadi yaitu menggunakan beberapa model APS seperti : Negosiasi, Pendapat Mengikat, Mediasi, Konsiliasi, Adjudikasi dan Arbitrase. ${ }^{13}$ Pada tahap awal sengketa, para pihak dianjurkan menempuh Negosiasi tanpa melibatkan pihak ketiga. Jika Negosiasi gagal, para pihak dapat mengundang pihak ketiga untuk membantu menyelesaikan sengketa. Pihak ketiga dapat berstatus sebagai ahli hukum, mediator, conciliator, adjudikator dan arbiter. ${ }^{14}$

Dalam hal ini para pihak yang dirugikan akibat penjualan data pribadi dapat menggunakan APS mediasi, adjudikasi dan arbitrase sebagaimana diatur dalam pasal 4 POJK No.1/POJK.O7/2014 tentang Lembaga Alternatif Penyelesaian Sengketa Di Sektor Jasa Keuangan, penyelesaian sengketa di luar pengadilan dilakukan melalui Lembaga Alternatif Penyelesaian Sengketa yang dimuat dalam Daftar Lembaga Alternatif Penyelesaian Sengketa yang ditetapkan oleh OJK.

Mediasi adalah adalah cara penyelesaian Sengketa melalui pihak ketiga yang ditunjuk oleh pihak yang bersengketa untuk membantu pihak yang bersengketa mencapai kesepakatan, Adjudikasi adalah cara penyelesaian Sengketa melalui pihak ketiga yang ditunjuk para pihak yang bersengketa untuk menjatuhkan putusan atas Sengketa yang timbul diantara pihak dimaksud, dan Yang dimaksud dengan arbitrase adalah cara penyelesaian suatu Sengketa perdata di luar peradilan yang didasarkan pada perjanjian arbitrase yang dibuat secara tertulis oleh para pihak yang bersengketa. Meskipun Adjudikasi belum diatur dalam UU 30/1999 tentang Arbitrase dan APS, namun cara ini sudah diatur dalam Peraturan OJK nomor 1/ POJK.o7/ 2014 tentang Lembaga APS di Sektor Jasa Keuangan.

Adjudikasi mirip dengan Arbitrase, namun prosesnya jauh lebih sederhana dan lebih cepat. Pihak pemohon diberikan hak opsi untuk menyetujui atau menolak hasil putusan Adjudikasi. Jika pemohon setuju maka putusan Adjudikasi dapat diberlakukan dan bersifat final dan mengikat. Pihak termohon (lembaga jasa keuangan) tidak diberi

\footnotetext{
${ }^{13}$ Iswi Hariyani dan Cita Yustisia Serfiyani, 2017, Perlindungan Hukum Dan Penyelesaian Sengketa Bisnis Jasa PMTekfin, vol 14, hal.353

${ }^{14}$ Ibid, hal.353
} 
hak opsi, sehingga harus menerima apapun hasil putusan Adjudikasi. Hak opsi semacam ini tidak dijumpai dalam proses Arbitrase. ${ }^{15}$

Selain itu, pihak yang dirugikan dapat mengajukan pengaduan dalam rangka penyelesaian sengketa data pribadi atas kegagalan perlindungan kerahasiaan data pribadinya oleh penyelenggara sistem elektronik kepada menteri sebagaimana disebutkan dalam pasal 26 huruf b Permenkominfo 20/2016 yang mengatakan: Pemilik data pribadi berhak mengajukan pengaduan dalam rangka penyelesaian sengketa data pribadi atas kegagalan perlindungan kerahasiaan data pribadinya oleh penyelenggara sistem elektronik kepada menteri, dan pasal 29: Setiap Pemilik Data Pribadi dan Penyelenggara Sistem Elektronik dapat mengajukan pengaduan kepada Menteri atas kegagalan perlindungan kerahasiaan Data Pribadi. Atas pelanggaran ketentuan perlindungan data pribadi menurut Pasal 36 ayat 1 Permenkominfo 20/2016 dapat diberikan sanksi sanksi peringatan lisan maupun tertulis, penghentian sementara kegiatan usaha dan/atau diumumkan melalui situs dalam jaringan (website online).

\section{D.Kesimpulan}

Jual beli data pribadi konsumen fintech merupakan perbuatan yang tidak sesuai dengan hukum positif karena jual beli data pribadi telah melanggar peraturan perundang-undangan yang terkait dengan penyalahgunaan data pribadi. Peraturan perundang-undang yang di langgar meliputi: UUPK, UU ITE, Peraturan Otoritas Jasa Keuangan, dan Peraturan Menteri Komunikasi dan Informatika. Peraturan perundangundangan yang dilanggar salah satunya yaitu Pasal 26 huruf a Peraturan Otoritas Jasa Keuangan Nomor 77/POJK.o1/2016 Tentang Layanan Pinjam Meminjam Uang Berbasis Teknologi Informasi yang menyatakan: "Penyelenggara wajib: Menjaga kerahasiaan, keutuhan, ketersediaan data pribadi, data transaksi, dan data keuangan yang dikelolanya sejak data diperoleh hingga data tersebut dimusnahkan”.

Konsumen fintech dapat melakukan upaya penyelesaian sengketa, akibat pelaku usaha gagal melindungi kerahasiaan data pribadi konsumen fintech dengan melakukan pengaduan pada Menteri Komunikasi dan Informatika, dan OJK (non litigasi), serta apabila tidak dapat terselesaikan konsumen dapat mengajukan gugatan ke pengadilan (litigasi).

\section{Daftar Pustaka}

Peter Mahmud Marzuki, Penelitian Hukum, cetakan keduabelas, (Jakarta: Prenada Media Group, 2016), hal.133-137

Suyud Margono, Penyelesaian Sengketa Bisnis: Alternative Dispute Resolution (ADR) : Teknik E Strategi Dalam Negosiasi, Mediasi E Arbitrase, (Bandung: Pustaka Reka Cipta, 2015), hal. 34

\footnotetext{
${ }^{15}$ Iswi Hariyani dan Cita Yustisia Serfiyani, 2016, Perlindungan Hukum bagi Nasabah Kecil dalam Proses Adjudikasi di Industri Jasa Keuangan, Jurnal Legislasi Indonesia, Vol.13, No.4, hal.421
} 
http://ejournal.uhn.ac.id/index.php/opinion

Yahya Harahap, Hukum Acara Perdata Tentang Gugatan, Persidangan, Penyitaan, Pembuktian, dan Putusan Pengadilan, (Jakarta: Sinar Grafika, 2009), hal.233-236

Nurnaningsih Amriani, Mediasi Alternatif Penyelesaian Sengketa di Pengadilan, (Jakarta: Grafindo Persada, 2012), hal.16

\section{Peraturan Perundang-undangan}

Kitab Undang-Undang Hukum Perdata.

Undang-Undang Nomor 19 Tahun 2016 Tentang Perubahan atas Undang-Undang Nomor 11 Tahun 2008 Tentang Informasi dan Transaksi Elektronik.

Undang-Undang Nomor 8 Tahun 1999 Tentang Perlindungan Konsumen.

Peraturan Pemerintah Republik Indonesia Nomor 82 Tahun 2012 Tentang Penyelenggaraan Sistem Dan Transaksi Elektronik.

Peraturan Otoritas Jasa Keuangan Nomor 1/POJK.o7/2013 Tentang Perlindungan Konsumen Sektor Jasa Keuangan.

Peraturan Otoritas Jasa Keuangan Nomor o1/POJK.07/2014 Tentang Lembaga Alternatif Penyelesaian Sengketa Di Sektor Jasa Keuangan.

Peraturan Otoritas Jasa Keuangan Nomor 77/POJK.o1/2016 Tentang Layanan Pinjam Meminjam Uang Berbasis Teknologi Informasi.

Peraturan Otoritas Jasa Keuangan Nomor 13/POJK.o2/ 2018 tentang Inovasi Keuangan Digital di Sektor Jasa Keuangan.

Peraturan Menteri Komunikasi dan Informatika Republik Indonesia Nomor 20 Tahun 2016 Tentang Perlindungan Data Pribadi Dalam Sistem Elektronik.

\section{Jurnal}

Sarwin Kiko Napitupulu dkk, 2017 Kajian Perlindungan Konsumen Sektor Jasa Keunagan:Perlindungan Konsumen Pada Fintech. (Jakarta: Otoritas Jasa Keungan), hal.8

Kornelius Benuf, Siti Mahmudah, dan Ery Agus Priyono. April 2019, Perlindungan Hukum Terhadap kemanan Data Konsumen Financial Techology Di Indonesia. Jurnal Ilmu Hukum Universitas Diponegoro. Volume 3 Nomor 2

Moch. Najib Imanullah, 2020, Aspek Hukum Peer To Peer Lending (Identifikasi Permasalahan Hukum dan Mekanisme Penyelesaian), Jurnal Privat Law Volume 8 Nomor 1, hal. 152

Kornelius Benuf, Siti Mahmudah, Ery Agus Priyono, 2019, Perlindungan Hukum Terhadap Keamanan Data Konsumen Financial Technology Di Indonesia, Jurnal Ilmu Hukum Universitas Kristen Satya Wacana, Volume 3 No 2, hal.151

Nasrudin, 2020, Upaya Penyelesaian Sengketa Pada Bisnis Pariwisata Di Tengah Pandemi Covid 19, Fakultas Syari'ah dan Hukum UIN Sunan Gunung Djati Bandung, vol 14, hal.84

Iswi Hariyani dan Cita Yustisia Serfiyani, 2017, Perlindungan Hukum Dan Penyelesaian Sengketa Bisnis Jasa PM-Tekfin, vol 14, hal.353

Iswi Hariyani dan Cita Yustisia Serfiyani, 2016, Perlindungan Hukum bagi Nasabah Kecil dalam Proses Adjudikasi di Industri Jasa Keuangan, Jurnal Legislasi Indonesia, Vol.13, No.4

\section{Internet}

https://maucash.id/pinjaman-online-langsung-cair-tanpa-ribet diakses pada tanggal, 17 Juni 2021, pukul 16:46 WIB

https://katadata.co.id/ariayudhistira/analisisdata/609a43a46aa5e/pencurian-data-pribadidalam-pusaran-bisnis-fintech-ilegal. Diakses pada tanggal 23 juli 2021, Pukul 15:32 WIB 